\title{
Kotimaista valkuaista broilereille
}

Petra Tuunainen ${ }^{1}$, Jarmo Valaja ${ }^{1}$, Eija Valkonen ${ }^{1}$, Jaakko Hiidenhovi ${ }^{1}$, Tuomo Tupasela ${ }^{1}$, Marja Hongisto ${ }^{2}$

${ }^{1}$ Maa- ja elintarviketalouden tutkimuskeskus, Jokioinen

${ }^{2}$ Rehuraisio Oy, Raisio

Siipikarjan valkuaisruokinta perustuu lähes täysin ulkomaisen soijan varaan. Soijan hintason ja saatavuuden vaihtelun takia valkuaistuotannon omavaraisuuden lisääminen on noussut jälleen keskustelunaiheeksi.

Siipikarjalle potentiaalisia kotimaisia valkuaisrehuja ovat rypsi, herne ja härkäpapu ja sinilupiini. Herneellä ja rypsillä on hyvä aminohappokoostumus ja ne sopivat hyvin täydentämään viljapohjaista rehua. Rypsi sisältää myös paljon ihmisen terveydelle edullisia omega-3- rasvahappoja. Tutkimuksen tavoitteena oli selvittää kotimaisista valkuaisrehuista, rypsirouheesta ja herneestä, valmistettujen rehujen vaikutuksia broilereiden tuotantotuloksiin ja lihan laatuun.

Kokeessa oli mukana noin 4000 Ross 308 - hybridin untuvikkoa. Koe kesti kuoriutumisesta teurastukseen. Starttirehuina käytettiin soijaa tai rypsin ja herneen sekoitusta ja kasvatusrehut sisälsivät joko soijaa tai rypsiä ja hernettä eri suhteessa (100/0 \%, 75/25 \% tai 50/50 \%).

Kokeessa havaittiin, että soijapohjaisella kontrollirehulla ruokittujen lintujen tuotantotulokset olivat kauttaaltaan parempia kuin koeryhmien tuotantotulokset: kasvu oli nopeampi, elopaino suurempi, rehunhyötysuhde parempi ja kuolleisuus matalampi. Pelkkää rypsipohjaista rehua syöneet linnut olivat pieniä ja kasvoivat huonosti sekä rehunkulutus oli pienempi ja rehunhyötysuhde huonompi kuin kontrolliryhmällä. Kuolleisuudessa ei havaittu eroja ryhmien välillä, mutta pelkkää rypsiä saaneista ryhmistä jouduttiin karsimaan heikkoja lintuja huomattavasti soijaa saanutta kontrolliryhmää enemmän, yli 20 \%. Herneen osuus rehussa nosti lintujen painoa ja myös kasvu oli nopeampaa. Samoin rehunkulutus nousi ja rehunhyötysuhde parani. Hernettä syöneillä myös kasvatuspoistuma oli pienempi kuin pelkkää rypsiä syöneillä ryhmillä.

Kotimaisella valkuaisella ruokittujen lintujen liha soveltui erittäin hyvin ihmisten ravinnoksi. Makutestissä kotimaisella valkuaisella ruokittujen lintujen liha sai paremmat pisteet mausta ja mehukkuudesta kuin kontrolliryhmä. Rasvahappoanalyysin perusteella kotimaisella valkuaisella ruokittujen lintujen lihassa tyydyttymättömien rasvahappojen kokonaismäärä oli suurempi ja tyydyttyneiden rasvahappojen kokonaismäärä pienempi kuin soijaa saaneella kontrolliryhmällä. Kun rehuun lisättiin hernettä, tyydyttyneiden rasvahappojen määrä kasvoi ja tyydyttymättömien määrä pieneni. Kotimaisella valkuaisella ruokittujen lintujen lihassa oli myös enemmän ihmisen terveydelle edullisia omega-3- rasvahappoja ja omega6/omega3- suhde parempi kuin kontrolliryhmällä. Pelkästään rypsiä saaneiden lintujen lihassa näiden rasvahappojen suhde oli myös merkitsevästi pienempi kuin hernettä saaneiden lintujen lihassa.

$\begin{array}{llll}\text { Asiasanat: } & \text { kotimainen, } & \text { rypsi, } & \text { herne, }\end{array}$ 


\section{Johdanto}

Siipikarjan valkuaisruokinta perustuu lähes täysin ulkomaisen soijan varaan. Tuontivalkuainen lisää kotieläinten salmonellatartuntariskiä ja GMO- soijan lisääntynyt käyttö aiheuttaa huolta kuluttajissa. Soijan hintatason ja saatavuuden vaihtelun takia valkuaistuotannon omavaraisuuden lisääminen on noussut jälleen keskustelunaiheeksi.

Siipikarjalle potentiaalisia kotimaisia valkuaisrehuja ovat rypsi, herne ja härkäpapu ja tulevaisuudessa sinilupiini. Herneellä ja rypsillä on hyvä aminohappokoostumus ja ne sopivat hyvin täydentämään viljapohjaista rehua (Cowieson ym. 2003). Herneessä on kuitenkin myös haitta-aineita, kuten tärkkelystä ja trypsiini inhibiittoreita. Haitta-aineet vähentävät herneen ravitsemuksellista arvoa. Rypsi sopii myös siipikarjan ravinnoksi (Szymeczko ym. 2010). Rypsi sisältää rikkipitoisia aminohappoja, kuten metioniinia, kysteiiniä ja threoniiniä, jotka täydentävät hyvin herneen aminohappokoostumusta, mutta myös paljon rehun sulavuutta huonontavia kuituja. Rypsi sisältää myös paljon ihmisen terveydelle edullisia omega-3- rasvahappoja. Broilerin lihan rasvahappokoostumuksella voi olla vaikutusta myös ihmisen ravitsemukselle.

Tutkimuksen tavoitteena oli selvittää kotimaisista valkuaisrehuista, rypsirouheesta ja herneestä, valmistettujen rehujen vaikutuksia broilereiden tuotantotuloksiin ja lihan laatuun.

\section{Aineisto ja menetelmät}

Kokeessa käytettiin noin 4000 Ross 308 - hybridin untuvikkoa, jotka jaettiin 48 karsinaan. Jokaiseen karsinaan tuli puolet kukkoja ja puolet kanoja, noin 83 eläintä per karsina. Koe kesti kuoriutumisesta teurastukseen (1-34 vuorokautta).

Kokeessa on seitsemän ruokintaryhmää:

1. Perinteinen rehu; soijapohjainen startti- ja kasvatusrehu (kontrolli)

2. Perinteinen soijapohjainen starttirehu ja rypsipohjaiset kasvatusrehut

3. Perinteinen soijapohjainen starttirehu ja rypsi-hernepohjainen kasvatusrehu (suhde 75:25)

4. Perinteinen soijapohjainen starttirehu ja rypsi-hernepohjainen kasvatusrehu (suhde 50:50)

5. Rypsi-hernepohjainen starttirehu ja rypsipohjaiset kasvatusrehut

6. Rypsi-hernepohjainen starttirehu ja rypsi-hernepohjaiset kasvatusrehut (suhde 75:25)

7. Rypsi-hernepohjainen starttirehu ja rypsi-hernepohjaiset kasvatusrehut (suhde 50:50)

Koerehut valmistettiin vehnästä, soijarouheesta, rypsirouheesta, herneestä, kasviöljystä, ruokintakalkista, monokalsiumfosfaatista, ruokasuolasta ja aminohapoista sekä vitamiini- ja hivenseoksista. Kaikkiin rehuihin lisättiin Betafinia (0,07 \%) ja Roxazyme G2 rehuentsyymiä (0,01 \%). Kokkidiostaattia (Elancoban200, 0,05 \%) käytettiin kaikissa rehuissa pois lukien loppukasvatusrehut. Poikasrehu rakeistettiin 3 mm:n ja kasvatusrehut 4 mm:n raekokoon.

Kokeen lopussa (33 pv) lopetettiin kaksi kukkolintua ryhmistä 1, 5, ja 7 ja niiden rintalihoista määritettiin rasvahappokoostumus. 


\section{Tulokset ja tulosten tarkastelu}

Koerehujen raaka-aine- ja laskennallinen koostumus sekä koerehujen analysoitu kemiallinen koostumus on esitetty taulukossa 1 , lintujen tuotantotulokset taulukossa 2 ja rintalihan rasvahappoanalyysin tulokset taulukossa 3.

Soijaa starttirehuna syöneiden lintujen elopainot olivat suurempia, kasvu oli nopeampaa, rehunhyötysuhde parempi ja kuolleisuus matalampi kuin rypsi-herne-starttirehua syöneiden lintujen. Samanlainen vaikutus on havaittavissa myös kasvatusrehuissa. Soijapohjaisella kontrollirehulla ruokittujen lintujen tuotantotulokset olivat kauttaaltaan parempia kuin koeryhmien tuotantotulokset: kasvu oli nopeampi, elopaino suurempi, rehunhyötysuhde parempi ja kuolleisuus matalampi. Pelkkää rypsirehua syöneet linnut olivat pieniä ja kasvoivat huonosti sekä rehunkulutus oli pienempi ja rehunhyötysuhde huonompi kuin kontrolliryhmällä. Kuolleisuudessa ei havaittu eroja ryhmien välillä, mutta pelkkää rypsiä saaneista ryhmistä jouduttiin karsimaan heikkoja lintuja huomattavasti soijaa saanutta kontrolliryhmää enemmän, yli 20 \%. Herneen osuus rehussa nosti lintujen painoa ja myös kasvu oli nopeampaa. Samoin rehunkulutus nousi ja rehunhyötysuhde parani ja rintalihan paino nousi. Hernettä syöneillä myös kasvatuspoistuma oli pienempi kuin pelkkää rypsiä syöneillä ryhmillä. Kun herneen määrää rehussa nostettiin 25 \%:sta 50 \%:iin, lintujen tuotantotulokset paranivat vielä enemmän.

Lintujen tuotantotulokset jäivät heikoiksi pelkällä rypsirehulla. Rypsi sisältää glukosinalaatteja, jotka vaikuttavat kilpirauhasten ja maksan toimintaan (McNeill ym. 2004). Aikaisemmissa tutkimuksissa on havaittu, että suuria määriä rypsiä käytettäessä rehuna broilereiden kasvu hidastuu, kuolleisuus lisääntyy ja rehunkulutus pienenee. Rypsillä on kokoonsa verrattuna myös varsin paljon kuorta (Jeroch ym. 2001). Kuoressa taas on paljon kuitua, joka häiritsee rypsin imeytymistä ja näin sen käyttämistä rehuna. Herne taas sisältää trypsiiniä inhiboivia haitta-aineita (McNeill ym. 2004) ja tärkkelystä (Cowieson ym. 2003), mutta tässä kokeessa herneen lisääminen rehuun paransi lintujen tuotantotuloksia ja vähensivät karsintaa.

Kuitenkin kotimaisella valkuaisella ruokittujen lintujen liha soveltui erittäin hyvin ihmisten ravinnoksi. Rasvahappoanalyysin perusteella kotimaisella valkuaisella ruokittujen lintujen lihassa tyydyttymättömien rasvahappojen kokonaismäärä oli suurempi ja tyydyttymättömien rasvahappojen kokonaismäärä pienempi kuin soijaa saaneella kontrolliryhmällä. Hernettä saaneilla linnuilla rintalihaksen tyydyttyneiden rasvahappojen määrä oli suurempi ja tyydyttymättömien määrä pienempi kuin pelkkää rypsiä saaneilla linnuilla. Samanlaisia tuloksia ovat saaneet myös Rahimi ym. (2011) ryhmineen, he käyttivät 15 \% rehunvalkuaisesta rypsiä ja havaitsivat monityydyttymättömiä rasvahappoja olevan lintujen rintalihassa enemmän kuin soija- ja maissipohjaista rehua saaneella kontrolliryhmällä.

Ihmisten ravinnossa omega6/omega3- suhde pitäisi olla noin 1, mutta länsimaisten ihmisten ruokavaliossa tavallisesti tämä suhde on noin 10-20 (Simopoulos 2004). Länsimaisten ihmisten ruokavaliossa on erityisesti liikaa omega 6- rasvahappoja, liian vähän omega3- rasvahappoja ja omega6/omega3- suhde on usein liian suuri. Liian suuren omega6/omega3- suhteen on huomattu lisäävän sydän- ja verisuonitautien sekä eri syöpien riskiä. Tässä kokeessa kotimaisella valkuaisella ruokittujen lintujen lihassa oli enemmän ihmisen terveydelle edullisia omega-3- ja omega-6- rasvahappoja ja omega6/omega3- suhde parempi kuin kontrolliryhmällä. Pelkästään rypsiä saaneiden lintujen lihassa näiden rasvahappojen suhde oli myös merkitsevästi pienempi kuin hernettä saaneiden lintujen lihassa. Länsimaisten ihmisten ruokavaliossa on erityisesti liikaa omega-6- rasvahappoja, liian vähän omega3- rasvahappoja ja omega-6/omega-3- suhde on usein liian suuri. 


\section{Johtopäätökset}

Soijaa starttirehuna saaneet linnut olivat kotimaisella valkuaista starttirehuna saaneisiin lintuihin verrattuna suurempia ja kasvoivat nopeammin sekä kokonaispoistuma oli pienempää. Pelkkää rypsirehua syöneet linnut olivat pieniä ja kasvoivat huonosti. Kasvatuspoistuma ja karsinta olivat huomattavan suurta pelkkää rypsiä syöneillä ryhmillä. Herneen osuus rehussa nosti lintujen painoa ja myös kasvu oli nopeampaa. Myös syöneillä kasvatuspoistuma oli pienempi kuin pelkkää rypsiä syöneillä ryhmillä. Kuitenkin kotimaisella valkuaisella ruokittujen lintujen liha soveltui hyvin ihmisten ravinnoksi. Makutestissä kotimaisella valkuaisella ruokittujen lintujen liha sai paremmat pisteet mausta ja mehukkuudesta kuin kontrolliryhmä. Samoin rasvahappoanalyysin perusteella kotimaisella valkuaisella ruokittujen lintujen lihassa tyydyttymättömien rasvahappojen kokonaismäärä oli suurempi ja omega6/omega3suhde parempi kuin kontrolliryhmällä.

Kaiken kaikkiaan kokonaan rypsiin perustuva ruokinta ei sovi sellaisenaan broilereille. Linnut jäävät heikoiksi, mikä nostaa karsinnan ja kokonaispoistuman määrää huomattavasti. Herne sopii broilereille rypsiä paremmin.

\section{Kirjallisuus}

Cowieson, A.J., Acamovic, T. \& Bedford M.R. 2003. Supplementation of diets containing pea meal with exogenous enzymes: effects on weight gain, feed conversion, nutrient digestibility and gross morphology of the gastrointestinal tract of growing broiler chicks. British Poultry Science 44 (3): 427-437 s.

Jeroch, H., Kracht, W. \& Dänicke, S. 2001. Feeding value of rape products and its improvement for broilers and laying hens. European Journal of Lipid Science Technology 103: 7-11 s.

McNeill, L., Bernard, K. \& McLeod, M.G. 2004. Food intake, growth rate, food conversion and food choice in broilers fed on diets high in rapeseed meal and pea meal, with observations on sensory evaluation of the resulting poultry meat. British Poultry Science 45: 519-523 s.

Rahimi, S., Kamran Azad, S. \& Karimi Torshizi, M.A. 2011. Omega-3 enrichment of broiler meat by using two oil seeds. Journal of Agricultural Science and Technology 13: 353-363 s.

Simopoulos, A.P. 2004. Omega-6/Omega-3 Essential fatty acid ratio and chronic diseases. Food Reviews International 20: 77-90 s.

Szymeczko, R., Topolínski, T., Burlokowska, K., Piotrowska, A., Boguslawska-Tryk, M. \& Blaszyk, J. 2010. Effects of different levels of rape seeds in the diet on performance, blood and bone parameters of broiler $\begin{array}{llllll}\text { chickens. Journal of Central European Agriculture } 11 & \text { (4): } 393-400 & \mathrm{~s} \text {. }\end{array}$ 
Taulukko 1. Starttirehujen (1-7 vrk), kasvatusrehujen (8-20 vrk), (21-29 vrk) ja (30-34 vrk) raaka-ainekoostumus (\%) ja analysoitu koostumus.

\begin{tabular}{|c|c|c|c|c|c|c|c|c|c|c|c|c|c|c|}
\hline \multirow[b]{2}{*}{ Ryhmä } & \multicolumn{2}{|c|}{ Starttirehu } & \multicolumn{4}{|c|}{ Kasvatusrehu 1} & \multicolumn{4}{|c|}{ Kasvatusrehu 2} & \multicolumn{4}{|c|}{ Loppukasvatusrehu } \\
\hline & $1-4$ & $5-7$ & 1 & $2+5$ & $3+6$ & $4+7$ & 1 & $2+5$ & $3+6$ & $4+7$ & 1 & $2+5$ & $3+6$ & $4+7$ \\
\hline & Soija & $\begin{array}{l}\text { Rypsi- } \\
\text { herne }\end{array}$ & $\begin{array}{l}\text { Kont- } \\
\text { rolli }\end{array}$ & $\mathrm{R}^{100}{ }^{1}$ & $\begin{array}{l}\mathrm{R} 75 / \mathrm{H} \\
25^{1}\end{array}$ & $\mathbf{R} 50 / \mathbf{H}^{5} 0^{1}$ & $\begin{array}{l}\text { Kont } \\
\text { rolli }\end{array}$ & $\mathrm{R}^{100^{1}}$ & $\begin{array}{l}\text { R75/H2 } \\
5^{1}\end{array}$ & $\begin{array}{l}\text { R50/H } \\
5^{1}\end{array}$ & $\begin{array}{l}\text { Kont- } \\
\text { rolli }\end{array}$ & $\mathrm{R}^{100^{1}}$ & $\begin{array}{l}\text { R75/H } \\
25^{1}\end{array}$ & $\begin{array}{l}\text { R50/H } \\
\mathbf{5 0}^{1}\end{array}$ \\
\hline \multicolumn{15}{|l|}{ Koostumus } \\
\hline Vehnä & 65,72 & 36,63 & 70,19 & 58,37 & 51,98 & 44,57 & 74,39 & 63,62 & 58,21 & 51,85 & 74,44 & 63,67 & 58,26 & 51,90 \\
\hline Rypsi & 0,00 & 24,50 & 0,00 & 33,00 & 26,70 & 19,30 & 0,00 & 28,46 & 22,97 & 16,59 & 0,00 & 28,46 & 22,97 & 16,59 \\
\hline Herne & 0,00 & 30,00 & 0,00 & 0,00 & 13,50 & 29,30 & 0,00 & 0,00 & 11,64 & 25,22 & 0,00 & 0,00 & 11,64 & 25,22 \\
\hline Soijarouhe & 27,50 & 0,00 & 24,50 & 0,00 & 0,00 & 0,00 & 20,60 & 0,00 & 0,00 & 0,00 & 20,60 & 0,00 & 0,00 & 0,00 \\
\hline Rypsiöljy & 1,64 & 4,00 & 0,35 & 4,00 & 3,10 & 2,02 & 0,25 & 3,48 & 2,67 & 1,75 & 0,25 & 3,48 & 2,67 & 1,75 \\
\hline Monokalsiumfosfaatti & 2,13 & 2,04 & 2,01 & 1,85 & 1,90 & 1,95 & 1,91 & 1,78 & 1,82 & 1,86 & 1,91 & 1,78 & 1,82 & 1,86 \\
\hline Ruokintakalkki & 1,33 & 1,07 & 1,41 & 1,03 & 1,11 & 1,21 & 1,41 & 1,07 & 1,14 & 1,23 & 1,41 & 1,07 & 1,14 & 1,23 \\
\hline Ruokasuola & 0,40 & 0,40 & 0,40 & 0,40 & 0,40 & 0,40 & 0,40 & 0,40 & 0,40 & 0,40 & 0,40 & 0,40 & 0,40 & 0,40 \\
\hline Kana-Hiven & 0,20 & 0,20 & 0,20 & 0,20 & 0,20 & 0,20 & 0,20 & 0,20 & 0,20 & 0,20 & 0,20 & 0,20 & 0,20 & 0,20 \\
\hline Broiler-Vita & 0,20 & 0,20 & 0,20 & 0,20 & 0,20 & 0,20 & 0,20 & 0,20 & 0,20 & 0,20 & 0,20 & 0,20 & 0,20 & 0,20 \\
\hline Metioniini & 0,17 & 0,22 & 0,14 & 0,15 & 0,17 & 0,20 & 0,12 & 0,12 & 0,14 & 0,16 & 0,12 & 0,12 & 0,14 & 0,16 \\
\hline Lysiini & 0,52 & 0,49 & 0,43 & 0,59 & 0,51 & 0,41 & 0,43 & 0,55 & 0,48 & 0,40 & 0,43 & 0,55 & 0,48 & 0,40 \\
\hline Threoniini & 0,14 & 0,20 & 0,12 & 0,17 & 0,18 & 0,19 & 0,04 & 0,07 & 0,08 & 0,10 & 0,04 & 0,07 & 0,08 & 0,10 \\
\hline Elancoban200 & 0,05 & 0,05 & 0,05 & 0,05 & 0,05 & 0,05 & 0,05 & 0,05 & 0,05 & 0,05 & 0,00 & 0,00 & 0,00 & 0,00 \\
\hline $\begin{array}{l}\text { Kuiva-aine, g/kg } \\
\text { g/kg kuiva-aineesta }\end{array}$ & 90,17 & 87,83 & 88,63 & 88,31 & 87,71 & 87,45 & 87,90 & 88,01 & 87,62 & 87,19 & 86,44 & 88,04 & 87,20 & 86,78 \\
\hline Tuhka & 65,50 & 64,20 & 71,60 & 66,10 & 65,90 & 59,40 & $\begin{array}{l}66,30 \\
202,9\end{array}$ & 68,00 & 67,10 & 68,00 & 66,10 & 68,90 & 66,90 & 64,50 \\
\hline Raakavalkuainen & 234,80 & 207,40 & 220,20 & 198,20 & 198,40 & 198,20 & 0 & 191,40 & 191,80 & 199,60 & 229,20 & 212,20 & 211,70 & 209,20 \\
\hline Raakarasva & 39,00 & 65,80 & 22,40 & 73,10 & 62,20 & 46,40 & 23,10 & 69,80 & 60,30 & 46,40 & 22,40 & 68,30 & 58,30 & 45,50 \\
\hline Raakakuitu & 25,90 & 55,70 & 23,30 & 60,10 & 56,50 & 51,00 & 24,40 & 58,20 & 55,80 & 48,60 & 25,60 & 51,60 & 51,00 & 47,00 \\
\hline
\end{tabular}

Lisäksi Betafini (0,07 \%) ja Roxazyme G2 rehuentsyymiä (0,01 \%).

${ }^{1} \mathrm{R} 100=100 \%$ soijapohjaisen kontrollirehun valkuaisesta korvattu rypsillä, R75/H25 = 25\% R100- rehun valkuaisesta korvattu herneellä, R50/H50 = 50\% R100- rehun valkuaisesta korvattu herneellä 
Taulukko 2. Broilerien tuotantotulokset kokeen aikana.

Ryhmä

\begin{tabular}{lll}
\hline 1 & 2 & 3
\end{tabular}

34

$100^{1}$

\begin{tabular}{|c|c|c|c|c|c|c|c|c|c|c|c|c|c|c|}
\hline Starttirehu & Soija & Soija & Soija & Soija & Rypsi-he & e Rypsi-he & Rypsi-h & SEM & $* \mathbf{C} 1$ & C 2 & C 3 & C 4 & C 5 & C 6 \\
\hline Elopaino, g & $2037,5^{\mathrm{a}}$ & $1609,5^{\mathrm{f}}$ & $1812,3^{\mathrm{d}}$ & $1958,6^{\mathrm{b}}$ & $1565,0^{\mathrm{g}}$ & $1732,7^{\mathrm{e}}$ & $1857,3^{c}$ & 12,040 & $<0,0001$ & $<0,0001$ & $<0,0001$ & $<0,0001$ & 0,033 & 0,3711 \\
\hline Kasvu, g/pv & $1994,9^{\mathrm{a}}$ & $1567,2^{f}$ & $1769,8^{\mathrm{d}}$ & $1916,3^{b}$ & $1522,7^{\mathrm{g}}$ & $1690,4^{\mathrm{e}}$ & $1814,9^{c}$ & 12,019 & $<0,0001$ & $<0,0001$ & $<0,0001$ & $<0,0001$ & 0,0331 & 0,3674 \\
\hline $\begin{array}{l}\text { Rehunkulutus } \\
\text { g/lintu/pv }\end{array}$ & $98,87^{\mathrm{a}}$ & $84,21^{\text {de }}$ & $90,70^{c}$ & $93,69^{b}$ & $76,58^{\mathrm{f}}$ & $83,32^{\mathrm{e}}$ & $85,94^{\mathrm{d}}$ & 0,804 & $<0,0001$ & $<0,0001$ & $<0,0001$ & 0,0015 & 0,9607 & 0,8242 \\
\hline RHS*** & $1,691^{\mathrm{d}}$ & $1,969^{\mathrm{a}}$ & $1,767^{\mathrm{C}}$ & $1,688^{\mathrm{d}}$ & $1,918^{\mathrm{b}}$ & $1,743^{\mathrm{c}}$ & $1,681^{\mathrm{d}}$ & 0,014 & $<0,0001$ & 0,0240 & $<0,0001$ & $<0,0001$ & 0,1489 & 0,5803 \\
\hline Kuolleisuus, \% & $2,420^{\mathrm{abc}}$ & $2,568^{\mathrm{abc}}$ & $1,025^{\mathrm{c}}$ & $1,902^{\mathrm{b}}$ & $3,457^{\mathrm{ab}}$ & $4,021^{\mathrm{a}}$ & $1,717^{\mathrm{c}}$ & 0,608 & 0,9677 & 0,0187 & 0,1185 & 0,2573 & 0,629 & 0,0143 \\
\hline Karsinta, \% & $0,600^{\mathrm{d}}$ & $23,233^{b}$ & $3,795^{\mathrm{d}}$ & $4,339^{d}$ & $29,365^{\mathrm{a}}$ & $9,482^{c}$ & $11,030^{\mathrm{C}}$ & 1,690 & $<0,0001$ & $<, 00001$ & $<0,0001$ & 0,5395 & 0,9847 & 0,768 \\
\hline
\end{tabular}

${ }^{1}$ R100 = 100\% soijapohjaisen kontrollirehun valkuaisesta korvattu rypsillä, R75/H25 = 25\% R100- rehun valkuaisesta korvattu herneellä, R50/H50 = 50\% R100- rehun valkuaisesta korvattu herneellä

*C1= valkuaisen lähteen vaikutus (ryhmä 1 vs. ryhmät 2, 3, 4, 5, 6 ja 7), C2= starttirehun vaikutus (ryhmät 2, 3 ja 4 vs. ryhmät 5, 6 ja 7), C3= rypsin valkuaisen korvaaminen herneellä (ryhmät 2 ja 5 vs. ryhmät 3, 4, 6 ja 7), C4= herneen lisäyksen tason vaikutukset (ryhmät 3 ja 6 vs. ryhmät 4 ja 7 ), C5=C2*C3 yhdysvaikutus, C6= C2*C4 yhdysvaikutus 
Taulukko 3. Rintalihanäytteiden rasvahappokoostumus, \%

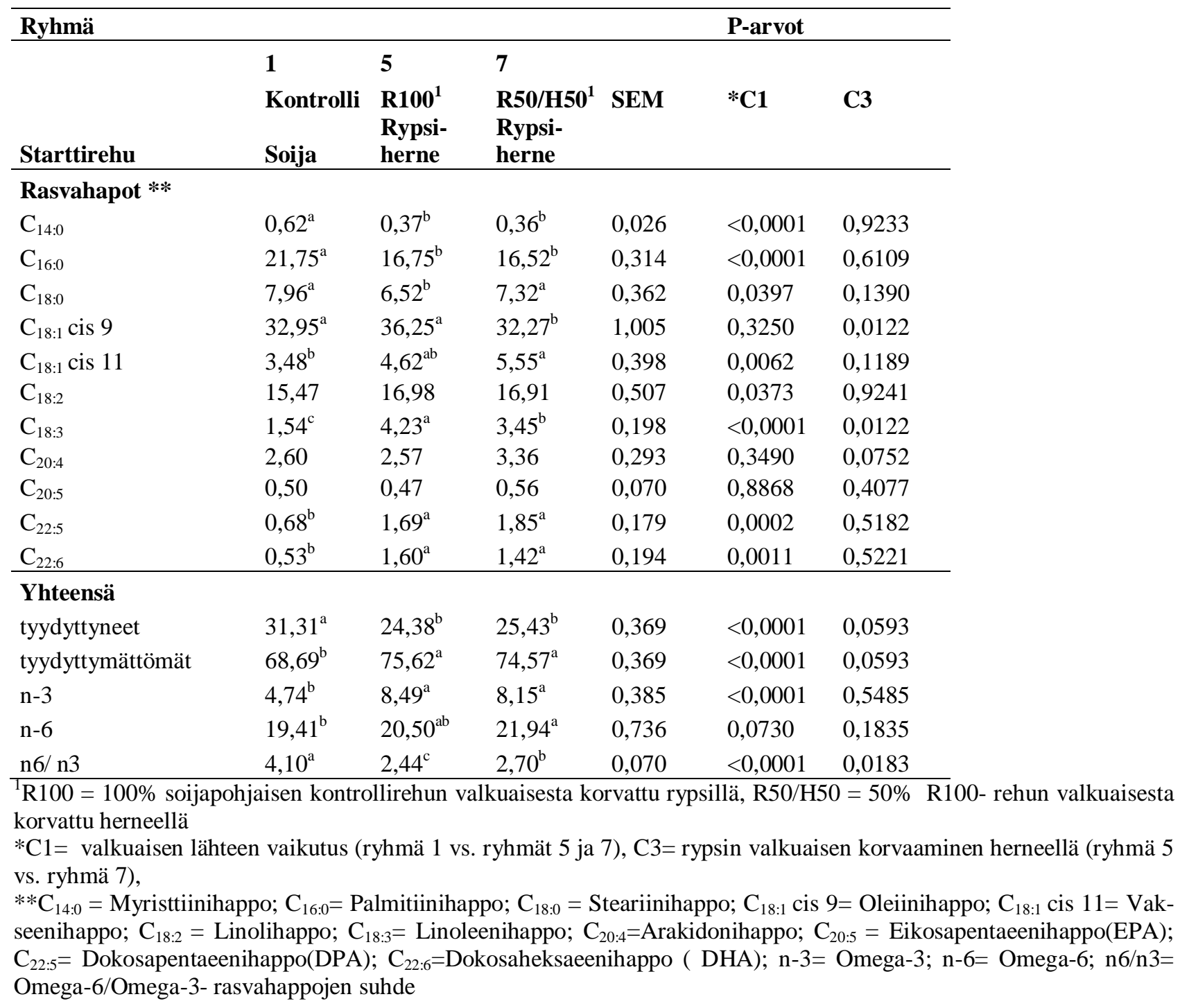

